UDC 66.094 .942

Yu. Melnyk, R. Starchevskyi, S. Melnyk

\title{
TRANSESTERIFICATION OF SUNFLOWER OIL TRIGLYCERIDES BY 1-BUTANOL IN THE PRESENCE OF D-METAL OXIDES
}

\author{
Lviv Polytechnic National University, Lviv, Ukraine
}

\begin{abstract}
The paper reports the results of the study on the transesterification of sunflower oil triglycerides with 1-butanol in the presence of d-metal oxides. It is shown that the initial rate of the transesterification reaction and the maximum conversion of triglycerides are differently affected by the oxides of different d-metal. A range of the activities of the investigated oxides is identified according to the initial reaction rate and triglyceride conversion attained. The oxides of zinc and nickel (II) are the most active catalysts. The use of ultrasound treatment in the transesterification reaction of triglycerides with 1butanol in the presence of iron (II) oxide allows increasing their conversion by about $16 \%$. However, even the application of the ultrasound treatment in the presence of the mentioned catalyst ensures a less conversion of triglycerides than that when using the oxides of nickel (II) and zinc. An increase in the molar ratio of triglycerides to 1-butanol up to 1:15 and $1: 20$ completely reduces the effect obtained by the application of ultrasound in the transesterification process. Thus, it is possible to achieve the triglyceride conversion of above $97 \%$ resulted from a 15 -fold increase in the molar excess of 1-butanol in the presence of nickel (II) and zinc oxides during $150 \mathrm{~min}$ of the reaction. A further increase in the molar ratio of reactants to 1:20 provides an almost complete conversion of triglycerides in the presence of these catalysts, the reaction duration simultaneously decreases to 120 min. There is an extremal dependence of the triglyceride conversion on the catalyst content $(\mathrm{FeO})$ in the reaction mixture. The optimal content of a catalyst in the reaction mixture is $0.25-0.30 \mathrm{wt} . \%$. The obtained results show that some d-metal oxides can be used as highly efficient catalysts of the transesterification reaction.
\end{abstract}

Keywords: transesterification, triglycerides, sunflower oil, oxides of d-metals, 1-butanol.

DOI: $10.32434 / 0321-4095-2019-125-4-95-100$

\section{Introduction}

Either sodium or potassium hydroxides are commonly used as catalysts in the transesterification reaction of vegetable oils and animal fats [1,2]. These reactions are mainly carried out using methanol or ethanol; however, today $\mathrm{C}_{3}$ and even $\mathrm{C}_{4}$ alcohols are employed in increasingly large number of studies [3]. The advantages of homogeneous alkaline catalysts are their comparatively low cost and high efficiency. The disadvantages include neutralization of catalyst, significant energy costs, difficulty in preparation of pharmaceutical-grade glycerol, wastewater treatment; in addition, saponification reliably occurb as a result of the interaction of triglycerides with alkali [4].

Homogeneous acid catalysts, heterogeneous acid-base catalysts, and lipase enzyme preparations are also used as catalysts for the transesterification of triglycerides by alcohols $[5,6]$.

Nowadays, the study of heterogeneous catalysts is brought into sharp focus. The main advantages of heterogeneous catalysis in the transesterification reaction are that the catalyst is easily separated from the reaction products, requiring no catalyst neutralization; catalyst reusability, not requiring to be regenerated; no saponification products; easier extraction of esters from glycerol and the ability to obtain high-purity glycerol; much smaller amount of wastewater; and minimum purification costs $[7,8]$.

Jitputti et al. [9] investigated heterogeneous catalysts for the transesterification reaction of coconut and palm oil, in particular the oxides $\mathrm{ZrO}_{2}$ and $\mathrm{ZnO}$. The process was performed at the temperature of $473 \mathrm{~K}$, the pressure of $5.0 \mathrm{MPa}$ and the molar ratio of triglycerides to methanol of 1:6. The conversion 
of triglycerides depending on the type of oil ranged from 80.2 to $87.5 \%$. Once the catalyst was extracted and regenerated, its initial activity was restored.

The application of $\mathrm{CaO} / \mathrm{Al}_{2} \mathrm{O}_{3}$ as a catalyst during the transesterification reaction of palm oil with methanol yielded $98.6 \%$ fatty acid methyl esters [7]. The reaction was carried out at the temperature of $338 \mathrm{~K}$ for 5 hours, the molar ratio of triglycerides to methanol was $1: 12$, and the catalyst content in the reaction mixture was 6 wt.\%. The disadvantage of the mentioned catalyst is its leaching, although the catalytic activity is maintained during three cycles.

The paper [10] reported the use of zeolites of $\mathrm{NaX}, \mathrm{NaY}, \mathrm{ETS}-10$ type and their analogues as catalysts for the transesterification reaction of vegetable oils. Among the investigated catalysts, the most active were silicon-titanium zeolites ETS-10 and ETS-10 modified with potassium (KETS10). The transesterification reaction was conducted for 24 hours at $393 \mathrm{~K}$, yielding $94.6 \%$ and $93.5 \%$ esters, respectively.

For the intensification of transesterification reaction, the use of microwave and ultrasound radiation is proposed. If microwave radiation is initially used as a means for rapid heat supply, then ultrasonic vibrations are employed to improve the agitation of a reaction mixture $[11,12]$.

The effects of energy of ultrasonic waves and microwave radiation on the process characteristics were investigated in the transesterification of sunflower and rapeseed oils by methanol in the presence of $\mathrm{MgO}$ catalyst [13]. The conversion of triglycerides has proven to surpass $99 \%$ even after the fifth cycle at the temperature of $343 \mathrm{~K}$ and the molar ratio of triglycerides to methanol of 1:4.

There is little evidence of the preparation of esters of higher fatty acids and alcohols containing more than two $\mathrm{C}$-atoms by the transesterification reaction using metal oxides as catalysts. Therefore, the purpose of this work was to study the transesterification of triglycerides with 1-butanol in the presence of d-metal oxides as heterogeneous catalysts.

\section{Experimental}

The transesterification reaction of triglycerides (TG) of sunflower oil by 1-butanol (BA) was investigated within the temperature range of 363$388 \mathrm{~K}$ using 1:(10-20) molar ratio of TG to BA. d-Metal oxides, including $\mathrm{FeO}, \mathrm{NiO}, \mathrm{ZnO}, \mathrm{CuO}$, $\mathrm{Co}_{2} \mathrm{O}_{3}$ and $\mathrm{Co}_{3} \mathrm{O}_{4}$, were used as catalysts for the transesterification reaction. All oxides were used in the form of fine powders. The content of catalyst was changed within $0.125-0.500 \mathrm{wt} . \%$.

Ultrasonic (US) treatment was applied in the reaction mixture by using UZDN-2T US generator over the whole reaction time. The US-radiation power was $400 \mathrm{~W}$ and the US-frequency was $22 \mathrm{kHz}$.

The transesterification reaction was conducted in a three-necked flask fitted with a reflux condenser and a thermometer. After some periods of time, the samples were removed from the reaction mixture where the content of BA was determined by means of chromatography technique. Based on the BA concentration in the reaction mixture, the amount of reacted alcohol was defined, followed by calculating the amount and conversion of the reacted triglycerides (in terms of triglyceride) [14].

The chromatographic analysis of the reaction mixture was performed using LHM-80 gas-liquid chromatograph with a thermal conductivity detector under the following conditions:

- the column of $3 \mathrm{~mm}$ in diameter and $2000 \mathrm{~mm}$ in length was filled with the stationary phase 5\% Silicone SE30 on Chromaton N-AW;

- helium was used as a carrier gas with a volumetric flow rate of $3.0 \mathrm{dm}^{3} / \mathrm{h}$;

- the temperature of columns thermostat was $393 \mathrm{~K}$, those of detector and evaporator were $493 \mathrm{~K}$ and $503 \mathrm{~K}$ respectively;

- the current intensity in the detector was $140 \mathrm{~mA}$;

- the volume of the analyzed sample was $2 \mu \mathrm{L}$.

\section{Results and discussions}

The effect of the catalyst type on the TG conversion was examined at the molar ratio of $\mathrm{TG}$ to BA of $1: 10$, the temperature of $383 \mathrm{~K}$ and thy catalyst content of $0.25 \mathrm{wt} . \%$. The highest TG conversion was achieved within $30 \mathrm{~min}$ of the reaction in the presence of nickel (II) oxide (Table). The least active catalysts were $\mathrm{Co}_{2} \mathrm{O}_{3}$ and $\mathrm{Co}_{3} \mathrm{O}_{4}$.

Final TG conversion is the highest in the 150th minute of the reaction in the presence of nickel (II) and zinc oxides. Moreover, zinc oxide as a catalyst yields TG a higher conversion (by 2.3\%). Both studied cobalt oxides exhibit a low activity in the 150th minute of the reaction like in its initial stage. Thus the catalysts can be divided into two groups according to the achieved TG conversion. The first group contains iron (II) and cobalt oxides, in the presence of which practically identical TG conversions are achieved, that is, approximately $60 \%$. Oxides of zinc, nickel (II), and copper (II) belong to the second group. TG conversion in the presence of oxides of the second group is found to be much higher (within the range of 78.2-83.8\%).

The obtained results show that TG conversion is differently affected by acoustic vibrations at various stages of the process (Table). 
The effect of the catalyst type on the conversion of sunflower oil triglycerides in the process of transesterification by 1-butanol

\begin{tabular}{c|c|c|c|c|c|c}
\hline \multirow{2}{*}{ Catalyst } & \multicolumn{4}{|c|}{ TG conversion, \% } & \multicolumn{2}{c}{ Initial reaction rate of transesterification $\left(\mathrm{r} \cdot 10^{4}\right)}$, \\
\cline { 2 - 5 } & \multicolumn{2}{|c|}{$30 \mathrm{~min}$} & \multicolumn{2}{c|}{$150 \mathrm{~min}$} & \multicolumn{2}{c}{$\mathrm{mol} /\left(\mathrm{dm}^{3} \cdot \mathrm{s}\right)$} \\
\cline { 2 - 7 } & without US & US & without US & US & without US & US \\
\hline $\mathrm{ZnO}$ & 42.5 & 47.3 & 83.8 & 82.3 & 1.3 & 1.4 \\
\hline $\mathrm{NiO}$ & 48.7 & 44.0 & 81.5 & 80.7 & 1.5 & 1.3 \\
\hline $\mathrm{CuO}$ & 38.9 & 37.3 & 78.2 & 75.7 & 1.2 & 1.1 \\
\hline $\mathrm{FeO}$ & 42.1 & 57.0 & 59.7 & 69.3 & 1.3 & 0.7 \\
\hline $\mathrm{Co}_{3} \mathrm{O}_{4}$ & 22.5 & 25.7 & 61.8 & 62.3 & 0.7 & 0.5 \\
\hline $\mathrm{Co}_{2} \mathrm{O}_{3}$ & 21.0 & 17.3 & 59.9 & 59.0 & 0.6 & 0.6 \\
\hline
\end{tabular}

Note: Temperature $383 \mathrm{~K}$, catalyst content $0.25 \mathrm{wt} . \%$, TG:BA molar ratio 1:10.

Thus, applying US treatment during the $\mathrm{NiO}$, $\mathrm{CuO}$, and $\mathrm{Co}_{2} \mathrm{O}_{3}$ catalyzed reactions leads to a 1.4$3.7 \%$ decrease in TG conversion in the initial stage as compared with the reaction without acoustic vibrations. In the presence of $\mathrm{ZnO}$ and $\mathrm{Co}_{3} \mathrm{O}_{4}$ catalysts, TG conversion, in contrast, increases by $3.2-4.8 \%$ under the action of US-waves. The US treatment in the case of the $\mathrm{FeO}$-catalyzed transesterification reaction results in the highest impact at the start of the reaction, and the TG conversion increases by $14.9 \%$.

As for the conversion of TG at deeper stages of their transformations, the influence of US-waves in the presence of all the catalysts was shown to be negligible, except for iron (II) oxide. The use of US-waves energy affects only the reaction catalyzed by iron (II) oxide. In this case, it is possible to achieve the TG conversion that is $9.6 \%$ higher than that when the US treatment is not involved. However, the TG conversion appears to be generally lower than in the presence of more active $\mathrm{NiO}$ and $\mathrm{ZnO}$ catalysts.

The initial rates of the transesterification of TG by 1-butanol in the presence of $\mathrm{ZnO}, \mathrm{NiO}, \mathrm{CoO}$ and $\mathrm{FeO}$ differ slightly and range within (1.1$1.5) \cdot 10^{-4} \mathrm{~mol} /\left(\mathrm{dm}^{3} \cdot \mathrm{s}\right)$. The rate of $1.7 \cdot 10^{-4} \mathrm{~mol} /\left(\mathrm{dm}^{3} \cdot \mathrm{s}\right)$ is achieved only in the reaction with the presence of $\mathrm{FeO}$ by applying the US treatment. The rate of the TG transesterification in the presence of cobalt oxides is 1.5-2.0 times lower than that with other oxide catalysts.

The results show that the studied catalysts, oxides of d-metals, can be ranged according to the reaction rate in the initial period in the following sequence:

$$
\mathrm{NiO}>\mathrm{ZnO} \approx \mathrm{FeOiCuO}>\mathrm{Co}_{3} \mathrm{O}_{4} \geq \mathrm{Co}_{2} \mathrm{O}_{3} .
$$

According to the maximum available $\mathrm{TG}$ conversion in the transesterification reaction without the use of US, the catalysts yield the following range, which is slightly different from the foregoing:

$$
\mathrm{ZnO} \approx \mathrm{NiO}>\mathrm{CuO}>\mathrm{FeO}>\mathrm{Co}_{3} \mathrm{O}_{4} \geq \mathrm{Co}_{2} \mathrm{O}_{3} .
$$

However, the range of the catalysts remains practically the same under the action of US-waves:

$$
\mathrm{ZnO} \approx \mathrm{NiO}>\mathrm{CuO}>\mathrm{Co}_{3} \mathrm{O}_{4} \approx \mathrm{FeO} \approx \mathrm{Co}_{2} \mathrm{O}_{3} .
$$

These sequences are close to those obtained while investigating the transesterification of sunflower oil TG by BA in the presence of a KU-2-8 cationexchange resin with immobilized metal ions as the catalyst [14]. The nickel-containing cation-exchange resin catalyst exhibited the highest activity whereas the activity of those catalysts that contained copper (II) and cobalt (II) was lower. This suggests that the activity of the metal cation is weakly affected by the method of the retention on the catalyst on the surface in the case of heterogeneous catalysis when the transesterification of TG is performed by 1-butanol.

It should be noted that higher TG conversion (the oxides of zinc, nickel (II), and copper (II)) is attained with the presence of catalysts which amphoteric properties are more strongly pronounced. This allows speculating that the acid-base properties may largely determine the catalytic activity of the studied oxides.

As the transesterification reaction is in equilibrium, an increase in the TG:BA molar ratio would increase the TG conversion. The effect of the molar ratio of reagents was explored for the transesterification reaction of TG in the presence of three following catalysts: oxides of zinc, nickel (II) and iron (II). Zinc and nickel (II) oxides showed the highest activity in the transesterification reaction. The most significant effect of US application on 
TG conversion was observed when using $\mathrm{FeO}$ catalyst.

The effect of the TG:BA ratio was studied at the temperature of $383 \mathrm{~K}$ and the catalyst content of $0.25 \mathrm{wt} . \%$. The molar ratio of TG to $\mathrm{BA}$ was changed within the range of 1:10-1:20. Increasing the TG:BA molar ratio was found to largely affects the TG conversion in the presence of all studied catalysts (Fig. 1).

Specifically, an increase in the TG:BA molar ratio from $1: 10$ to $1: 15$ results in an increase of the TG conversion of about $16 \%$ in the presence of zinc and nickel (II) oxides, while an increase of $34 \%$ or more is achieved with $\mathrm{FeO}$ under the same conditions. At the reported molar ratio of reagents, the maximum TG conversion in the presence of nickel (II) and zinc oxides goes beyond $97 \%$ and is only $94 \%$ in the presence of $\mathrm{FeO}$ catalyst. A further increase in the TG:BA molar ratio (to 1:20) has an increasingly lower effect on the conversion of TG within $150 \mathrm{~min}$. Nevertheless, the presence of all studied catalysts at the mentioned ratio gives an almost complete TG conversion. It takes $120 \mathrm{~min}$ for the reaction to achieve the complete conversion of TG in the presence of zinc and nickel (II) oxides, whereas the use of iron (II) oxide as a catalyst requires $150 \mathrm{~min}$ of the reaction time to approach $100 \% \mathrm{TG}$ conversion.

Furthermore, it was determined that the effect of the application of US-waves with increasing the TG:BA molar ratio in the presence of iron (II) oxide initially disappears (at the TG:BA molar ratio of $1: 15)$ and then becomes negative. This means that the TG conversion under the US treatment is $1.6 \%$ lower than that in its absence (the TG:BA molar ratio of 1:20).

The effect of the content of the iron (II) oxide catalyst on the transesterification reaction was investigated at the temperature of $383 \mathrm{~K}$ and the TG:BA molar ratio of 1:10 in the $0.125-0.500 \mathrm{wt} . \%$ range of the catalyst content both with and without US treatment (Fig. 2).

The maximum achieved TG conversion was found to show an extreme dependence on the content of catalyst in the reaction mixture. Both in case of the US application and in its absence, the maximum TG conversion is observed in the range of $0.25-$ $0.3 \mathrm{wt} . \%$. The resulting extreme dependences of the TG conversion on the catalyst concentration in the transesterification reaction of TG with 1-butanol in the presence of d-metal oxides are in agreement with those typical of the catalysis of TG transesterification with metal ions immobilized on KU-2-8 cationexchange resin [14]. The efficiency resulted from an increase in the content of metal oxide in the reaction mixture is likely to be insufficient even with the application of US treatment. This will cause a significant part of the catalyst to precipitate and, accordingly, there will be a decrease in the TG conversion.

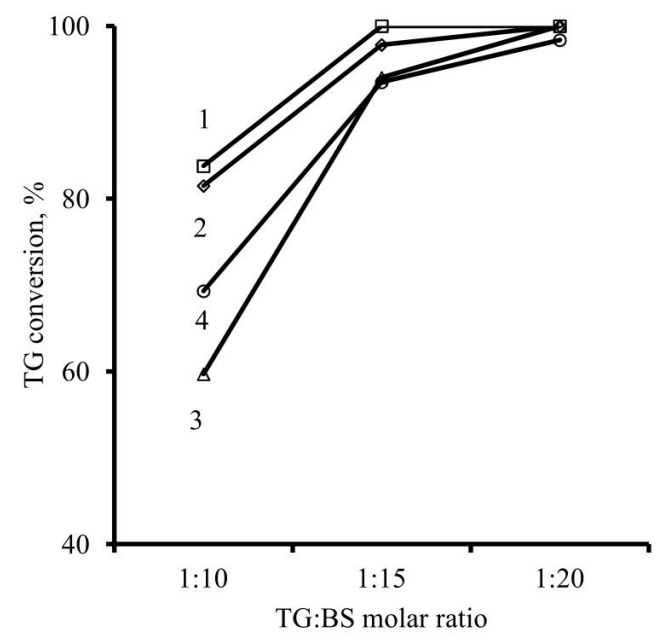

Fig. 1. The dependence of the conversion of triglycerides on the TG:BA molar ratio for zinc oxide (1), nickel (II) oxide (2), iron (II) oxide (3) and when using US treatment (4). The reaction temperature is $383 \mathrm{~K}$, the reaction duration is 150 $\mathrm{min}$, the catalyst content is $0.25 \mathrm{wt} . \%$

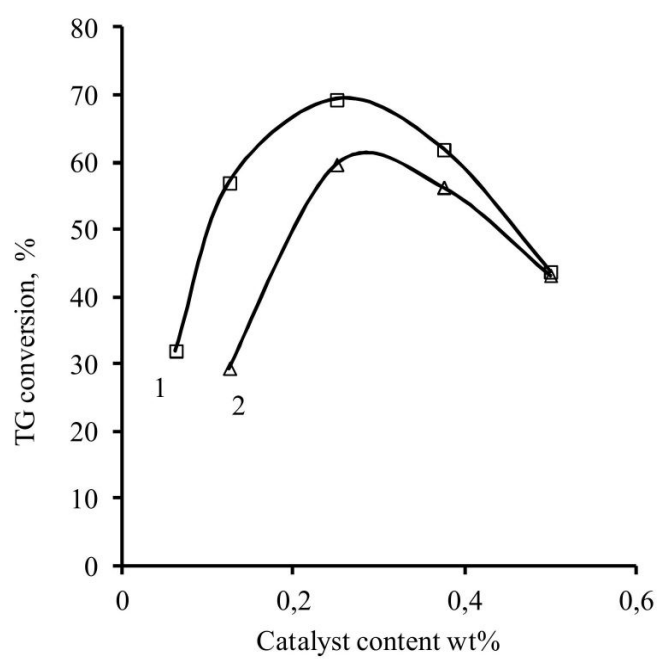

Fig. 2. The dependence of the conversion of TG on the content of the iron (II) oxide catalyst under the action of US (1) and without US threatment (2). The reaction temperature is $383 \mathrm{~K}$, the reaction duration is $150 \mathrm{~min}$, the TG:BA molar ratio is $1: 10$ 


\section{Conclusions}

The conversion of TG largely depends on the type of the catalyst, a d-metal oxide. The oxides of zinc and nickel were found to be the most active catalysts.

The application of the US-waves in the transesterification process was demonstrated to be effective only in the presence of $\mathrm{FeO}$ catalyst. It was determined that the effect of US treatment would be diminish or become negative with increasing the TG:BA molar ratio to $1: 15$.

An increase in the TG:BA molar ratio to $1: 15$ allows reaching above $97 \%$ TG conversion for 150 min of reaction in the presence of the zinc and nickel(II) oxides as catalysts. A further rise of the TG:BA molar ratio to $1: 20$ yields the complete TG conversion in the presence of these catalysts already after $120 \mathrm{~min}$.

The TG conversion shows an extreme dependence on the content of $\mathrm{FeO}$ catalyst both when using US treatment and without US treatment.

Therefore, it can be argued that d-metal oxides are effective catalysts for the transesterification of sunflower oil by 1-butanol. The optimal reaction conditions are as follows: the reaction temperature of $383 \mathrm{~K}$, the catalyst content of zinc or nickel(II) oxide of $0.25 \mathrm{wt} . \%$, the TG:BA molar ratio of reagents of 1:15 and the reaction duration of $150 \mathrm{~min}$. Under these conditions, the TG conversion will be equal to $100 \%$ and $97.8 \%$ in the presence of zinc oxide and nickel(II) oxide, respectively.

\section{REFERENCES}

1. Eevera T., Rajendran K., Saradha S. Biodiesel production process optimization and characterization to assess the suitability of the product for varied environmental conditions // Renew. Energy. - 2009. - Vol.34. - P.762-765.

2. Vyas A.P., Verma J.L., Subrahmanyam N. Effects of molar ratio, alkali catalyst concentration and temperature on transesterification of Jatropha oil with methanol under ultrasonic irradiation // Adv. Chem. Eng. Sci. - 2011. - Vol.1. - P.45-50.

3. Patryliak L.K., Zubko S.O., Konovalov S.V. Pereesteryfikatsiia ripakovoiyi oliyi butanolom na luzhnykh katalizatorakh // Voprosy Khimii i Khimicheskoi Tekhnologi. 2018. - No. 5. - P.125-130.

4. Catalytic applications in the production of biodiesel from vegetable oils / Sivasamy A., Cheah K.Y., Fornasiero P., Kemausuor F., Zinoviev S., Miertus S. // ChemSusChem. 2009. - Vol.2. - P.278-300.

5. Singh S.P., Singh D. Biodiesel production through the use of different sources and characterization of oils and their esters as the substitute of diesel: a review // Renew. Sustainable
Energy Rev. - 2010. - Vol.14. - P.200-216.

6. Leung D.Y.C., Wu X., Leung M.K.H. A review on biodiesel production using catalyzed transesterification // Appl. Energy. 2010. - Vol.87. - No. 1. - P.1083-1095.

7. Zabeti M., Daud W.M.A.W., Aroua M.K. Activity of solid catalysts for biodiesel production: A review // Fuel Process. Technol. - 2009. - Vol.90. - No. 6. - P.770-777.

8. Endalew A.K., Kiros Y., Zanzi R. Heterogeneous catalysis for biodiesel production from Jatropha curcas oil (JCO) // Energy. - 2011. - Vol.36. - No.5. - P.2693-2700.

9. Transesterification of crude palm kernel oil and crude coconut by different solid catalysts / Jitputti J., Kitiyanan P., Rangsunvigit K., Bunyakiat K. Attanatho L., Jenvanitpanjakul P. // Chem. Eng. J. - 2006. - Vol.116. - No. 1. - P.61-66.

10. Xie W., Huang X., Li H. Soybean oil methyl esters preparation using $\mathrm{NaX}$ zeolites loaded with $\mathrm{KOH}$ as a heterogeneous catalyst // Bioresour. Technol. - 2007. - Vol.98. - No. 4. - P.936-939.

11. Cleaner production of methyl ester from non-edible feedstock by ultrasonic-assisted cavitation system / Asif S., Chuah L.F., Klemes J.J., Ahmad M., Akbar M.M., Lee K.T., Fatima A. // J. Clean. Prod. - 2017. - Vol.161. - P.1360-1373.

12. Gude V.G. Synergism of microwaves and ultrasound for advanced biorefineries // Resource-Eficient Technol. - 2015. - Vol.1. - P.116-125.

13. Sunflower and rapeseed oil transesterification to biodiesel over different nanocrystalline MgO catalysts / Verziu M., Cojocaru B., Hu J., Richards R., Ciuculescu C., Filip P., Parvulescu V.I. // Green Chem. - 2008. - Vol.10. - P.373-381.

14. Research into transesterification of triglycerides by aliphatic alcohols $\mathrm{C}_{2}-\mathrm{C}_{4}$ in the presence of ionites / Yu. Melnyk, S. Melnyk, Z. Palyukh, B. Dzinyak // Eastern-European J. Enterprise Technol. - 2018. - Vol.1. - No. 6. - P.10-16.

Received 27.03.2019

\section{ТРАНСЕСТЕРИФІКАЦІЯ ТРИГЛІЦЕРИДІВ СОНЯШНИКОВОЇ ОЛІЇ БУТАН-1-ОЛОМ У ПРИСУТНОСТІ ОКСИДІВ D-МЕТАЛІВ}

\section{Ю.Р. Мельник, Р.О. Стариевський, С.Р Мельник}

Наведено результати дослідження закономірностей трансестерифікації тригліцеридів соняшникової олії бутан-1олом у присутності оксидів $d$-металів. Показано, що оксиди $d$-металів по-різному впливають на початкову швидкість реакції трансестерифікації та максимальну конверсію тригліцеридів. Встановлено ряд активності досліджених оксидів за початковою швидкістю реакиії та досягнутою конверсією тригліцеридів. Показано, що найактивнішими каталізаторами є оксиди Цинку та Нікелю. Встановлено, що використання ультразвуку в процесі трансестерифікації тригліцеридів бутан-1-олом у присутності оксиду Феруму(II) дозволяє підвищити їхню конверсію приблизно на 16\%. Проте, навіть застосування енергії ультразвукових коливань у присутності иього каталізатора забезпечує конверсію тригліцеридів меншу, ніж при використанні оксидів Нікелю та Цинку. Також показано, що збільшення мольного співвідношення тригліцериди:бутан-1- 
ол до 1:15 та 1:20 повністю нівелює ефект отриманий від застосування ультразвуку в процесі трансестерифікації. Зокрема збільшення мольного надлишку бутан-1-олу в 15 разів дозволяє за 150 хв реакиї досягти в присутності оксидів Нікелю та Цинку конверсії тригліцеридів понад 97\%. Показано, що подальше підвищення мольного співвідношення реагентів до 1:20 забезпечує практично повне перетворення тригліцеридів у присутності иих каталізаторів при одночасному зменшенні тривалості реакції до 120 хв. Встановлено, екстремальну залежність конверсії тригліцеридів від вмісту каталізатора (ферум(II) оксиду) у реакційній суміші. Показано, що оптимальний вміст каталізатора в реакційній суміші становить 0,25-0,30 мас.\%. Отримані результати, вказують на придатність деяких оксидів d-металів до застосування як високоефективних каталізаторів реакції трансестерифікації.

Ключові слова: трансестерифікація, тригліцериди, соняшникова олія, оксиди d-металів, бутан-1-ол.

\section{TRANSESTERIFICATION OF SUNFLOWER OIL TRIGLYCERIDES BY 1-BUTANOL IN THE PRESENCE OF D-METAL OXIDES}

\author{
Yu. Melnyk *, R. Starchevskyi, S. Melnyk \\ Lviv Polytechnic National University, Lviv, Ukraine \\ *e-mail: yurii.r.melnyk@lpnu.ua
}

The paper reports the results of the study on the transesterification of sunflower oil triglycerides with 1-butanol in the presence of $d$-metal oxides. It is shown that the initial rate of the transesterification reaction and the maximum conversion of triglycerides are differently affected by the oxides of different $d$ metal. A range of the activities of the investigated oxides is identified according to the initial reaction rate and triglyceride conversion attained. The oxides of zinc and nickel (II) are the most active catalysts. The use of ultrasound treatment in the transesterification reaction of triglycerides with 1-butanol in the presence of iron (II) oxide allows increasing their conversion by about 16\%. However, even the application of the ultrasound treatment in the presence of the mentioned catalyst ensures a less conversion of triglycerides than that when using the oxides of nickel (II) and zinc. An increase in the molar ratio of triglycerides to 1-butanol up to 1:15 and 1:20 completely reduces the effect obtained by the application of ultrasound in the transesterification process. Thus, it is possible to achieve the triglyceride conversion of above $97 \%$ resulted from a 15-fold increase in the molar excess of 1-butanol in the presence of nickel (II) and zinc oxides during 150 min of the reaction. A further increase in the molar ratio of reactants to 1:20 provides an almost complete conversion of triglycerides in the presence of these catalysts, the reaction duration simultaneously decreases to $120 \mathrm{~min}$. There is an extremal dependence of the triglyceride conversion on the catalyst content $(\mathrm{FeO})$ in the reaction mixture. The optimal content of a catalyst in the reaction mixture is $0.25-0.30 \mathrm{wt} . \%$. The obtained results show that some $d$ metal oxides can be used as highly efficient catalysts of the transesterification reaction.

Keywords: transesterification; triglycerides; sunflower oil; oxides of d-metals; 1-butanol.

\section{REFERENCES}

1. Eevera T., Rajendran K., Saradha S. Biodiesel production process optimization and characterization to assess the suitability of the product for varied environmental conditions. Renewable Energy, 2009, vol. 34, pp. 762-765.

2. Vyas A.P., Verma J.L., Subrahmanyam N. Effects of molar ratio, alkali catalyst concentration and temperature on transesterification of Jatropha oil with methanol under ultrasonic irradiation. Advances in Chemical Engineering and Science, 2011, vol. 1 , pp. $45-50$.

3. Patrylak L.K., Zubenko S.O., Konovalov S.V. Pereesteryfikatsiya ripakovoyi olii butanolom na luzhnykh katalizatorakh [Transesterification of rapeseed oil by butanol over alkaline catalysts]. Voprosy Khimii i Khimicheskoi Tekhnologii, 2018, vol. 5, pp. 125-130. (in Ukrainian).

4. Sivasamy A., Cheah K.Y., Fornasiero P., Kemausuor F., Zinoviev S., Miertus S. Catalytic applications in the production of biodiesel from vegetable oils. ChemSusChem, 2009, vol. 2, pp. 278-300.

5. Singh S.P., Singh D. Biodiesel production through the use of different sources and characterization of oils and their esters as the substitute of diesel: a review. Renewable and Sustainable Energy Reviews, 2010, vol. 14, pp. 200-216.

6. Leung D.Y.C., Wu X., Leung M.K.H. A review on biodiesel production using catalyzed transesterification. Applied Energy, 2010, vol. 87, pp. 1083-1095.

7. Zabeti M., Daud W.M.A.W., Aroua M.K. Activity of solid catalysts for biodiesel production: a review. Fuel Processing Technology, 2009, vol. 90, pp. 770-777.

8. Endalew A.K., Kiros Y., Zanzi R. Heterogeneous catalysis for biodiesel production from Jatropha curcas oil (JCO). Energy, 2011, vol. 36, pp. 2693-2700.

9. Jitputti J., Kitiyanan P., Rangsunvigit K., Bunyakiat K. Attanatho L., Jenvanitpanjakul P. Transesterification of crude palm kernel oil and crude coconut by different solid catalysts. Chemical Engineering Journal, 2006, vol. 116, pp. 61-66.

10. Xie W., Huang X., Li H. Soybean oil methyl esters preparation using $\mathrm{NaX}$ zeolites loaded with $\mathrm{KOH}$ as a heterogeneous catalyst. Bioresource Technology, 2007, vol. 98, pp. 936-939.

11. Asif S., Chuah L.F., Klemes J.J., Ahmad M., Akbar M.M., Lee K.T., Fatima A. Cleaner production of methyl ester from non-edible feedstock by ultrasonic-assisted cavitation system. Journal of Cleaner Production, 2017, vol. 161, pp. 1360-1373.

12. Gude V.G. Synergism of microwaves and ultrasound for advanced biorefineries. Resource-Eficient Technologies, 2015, vol. 1, pp. 116-125.

13. Verziu M., Cojocaru B., Hu J., Richards R., Ciuculescu C., Filip P., Parvulescu V.I. Sunflower and rapeseed oil transesterification to biodiesel over different nanocrystalline $\mathrm{MgO}$ catalysts. Green Chemistry, 2008, vol. 10, pp. 373-381.

14. Melnyk Yu., Melnyk S., Palyukh Z., Dzinyak B. Research into transesterification of triglycerides by aliphatic alcohols $\mathrm{C}_{2}-\mathrm{C}_{4}$ in the presence of ionites. Eastern-European Journal of Enterprise Technologies, 2018, vol. 1, no. 6, pp. 10-16. 